\title{
Role of Dynamic Capabilities in the Performance of Manufacturing Firms in Nairobi County, Kenya
}

\author{
Thomas O. Nyachanchu \\ School of Business and Economics, Moi University, Kenya \\ Joel Chepkwony PhD \\ Ronald Bonuke PhD \\ Dept. of Marketing and Logistics, SBE, Moi University, Kenya
}

Doi: 10.19044/esj.2017.v13n31p438 URL:http://dx.doi.org/10.19044/esj.2017.v13n31p438

\begin{abstract}
The advent of globalization has brought with it drastic changes to the operating landscape for firms in the manufacturing sector. The need for transformational changes so as sustain competitive advantage has been on the rise. Firms are expected to continuously re-engineer their business models and operations to catch up with the turbulent environment. Previous studies have investigated the contribution of manufacturing firms in economic growth. Some have concentrated on the preferred approaches that countries should take, whether protectionism or free market. However, empirical studies investigating direct impact of dynamic capabilities on manufacturing firms' performance have been minimal. The general objective of the study was to examine the influence of the three dimensions of dynamic capabilities (sensing capabilities, seizing capabilities and reconfiguration capabilities) on firm performance. The study was grounded on the Resource-Based View theory. An explanatory research design was used for the cross-sectional survey. Primary data was obtained from 271 out of 369 firms sampled from a population of 1,496 manufacturing firms in Nairobi County, Kenya, using a structured questionnaire instrument through drop and pick. The questionnaire was completed by the firms' CEOs. Reliability and validity tests were carried out on the research instruments and study measures. Hypotheses were tested using regression analysis results, namely: - sensing capabilities $(B=0.215, \mathrm{P}<0.01)$, seizing capabilities $(B=0.194, \mathrm{P}<0.01)$ and reconfiguration capabilities $(B=0.182, \mathrm{P}<0.001)$. These three variables combined, contributed $25.9 \% \quad\left(\mathrm{R}^{2}=0.259\right)$ of the variance in firm performance. The study concluded that deployment of dynamic capabilities has significant influence on firm performance.
\end{abstract}


Keywords: Firm Performance, Sensing Capabilities, Seizing Capabilities, Reconfiguration Capabilities.

\section{Introduction:}

Manufacturing firms are faced with indeterminate changes in consumer demands, technology, competition and globalization, among many aspects. The competitive environment is shifting each day leading to a high level of uncertainty which affects firm performance (Wilden et al, 2013). Those firms that create and sustain competitive advantage are the only ones that survive (Zott, 2003; Wilden et al, 2013). The Resource-Based-View (RBV) theory posits that firms in the same industry perform differently owing to different stocks of resources they hold, their level of information (Barney, 2005) on these resources and the extent to which they control and deploy capabilities (Jantunen, 2005; Halawi et al., 2006) to harness the same. Firms are expected to have a contingent creative search in the form of dynamic capabilities or routines, which they apply to achieve enhanced resource configurations so as to remain relevant even as markets emerge, collide, split, evolve, or die (Eisenhardt and Martin, 2000; Winter, 2003).

In the more developed economies, manufacturing firms are realizing that in order to survive they must re-focus upstream on the value chain (Bititci, et al, 2010). This is to enable them to compete not on cost, but on value innovation, process excellence and sustainability (Bititci, et al, 2010). In Africa, even long after their independence, many countries' political changes have continued to influence the rate and level of growth of their manufacturing sectors. This politically driven sectoral growth has not been sustainable (Adenikinju, et al, 2002). The sectors have remained small, with high attrition rate and they lack in effective policy frameworks to support firms that operate in these unstable environments (Hatton \& Williamson, 2003). In Kenya, despite the expectation that the manufacturing sector would be a key driver of foreign exchange earnings, many firms have either closed down or shifted business elsewhere (Kenya Economic Update Report 2013/2014).

In unstable market environments, ordinary capabilities become unsuitable for firms to cope (Chmielewski \& Paladino, 2007; Helfat et al., 2009). That is why an offshoot of the Resource-Based-View theory, i.e. the Dynamic Capabilities theory, holds that firms are expected to innovate and renew resources and core competences for use (Ramachandran, 2011). These are higher level capabilities that extend, modify, change, and create resources and ordinary capabilities towards the fundamental role in decision options to improve performance (Eisenhardt and Martin, 2000; Winter, 2003). Literature shows a link between market turbulence, competitive intensity and environmental dynamism (Chmielewski and Paladino, 2007; 
Tallon, 2008). Firms therefore ought to frequently and speedly search for opportunities or new business markets (Zahra \& George, 2002), and to reconfigure their products, services and internal business process models so as to match the shifting customer behaviour (Zahra \& George, 2002). Although previous studies have attempted to relate dynamic capabilities to entrepreneural capabilities (Aramand \& Valliere, 2012), little effort has been made to directly link the concept of dynamic capabilities to firm performance.

\section{Literature Review}

In order to understand the concepts of firm performance and dynamic capabilities, literature on the two constructs was reviewed. This enabled the study to conceptualize the variable interplays and also determine their measures.

\section{Firm Performance}

Both financial and non-financial performance dimensions were reviewed. Financial performance is the ability of the firm to satisfy investors and stockholders; and is represented by profitability, growth and market value (Farjoun, 2002; Li and Liu, 2014; Glick et al 2005, Santos and Brito, 2012; Arend, 2014). Profitability measures an organization's past ability to generate returns (Glick et al., 2005). Growth in sales is a firm's past ability to increase its business coverage (Whetten, 2006) and to bring about economies of scale and market power which leads to future profitability. Market share has a correlation with historical profitability and growth levels and therefore represents the external assessment of a firm's future performance. In modern-day world, customers want firms to provide them with goods and services that match their expectations (Cronin et al., 2000). To do that, manufacturing firms avoid defects as they strive to improve the perceived quality and value add on their offerings. Customer satisfaction increases the willingness-to-pay and thus the perceived value created by a firm (Barney \& Clark, 2007). Employees, on the other hand, obtain their satisfaction from investments in good human resource practices. The satisfaction of employees is a reflection of a firm's ability to attract and retain employees and to lower their attrition rates (Farjoun, 2002). Social and environmental performance is also a way of satisfying local communities (Farjoun, 2002) and governments, among other stakeholders. Satisfaction indeces associated with these groups are safe environmental practices, increased product quality and safety, ethical advertising, minority employment and development of social projects (Polonsky \& Scott, 2005; Filatotchev et al., 2009; Park and Luo, 2001; Santos and Brito, 2012). The study therefore adapted firm performance measures from previous empirical 
research, namely: - profitability, growth in sales, market share, customer satisfaction, employee satisfaction, environmental performance and social performance (Santos and Brito, 2012; Combs et al., 2005; Carton and Hofer, 2006; Richard et al., 2009).

\section{Dynamic Capabilities}

Dynamic capabilities represent a class of higher order capabilities that influence the rate at which a firm is able to respond to environmental changes (Easterby-Smith et al., 2009; Winter, 2003). This is the repeatable, patterned choices and routines that provide capacity for a firm to purposefully create, extend, or modify its resource base (Helfat, et al., 2009). They include sensing capabilities, seizing capabilities, and reconfiguration capabilities (Teece, 2007).

Sensing capabilities involves recognition and monitoring of opportunities and threats from both the external and internal environment. The study adopted measures that have been used in previous studies (Danneels, 2008; Jansen et al., 2008; Lichtenthaler, 2009). Two scales were adapted for this variable. The first scale was the recognition of opportunities and threats from the environment (Cao, 2011; Lichtenthaler, 2009; Danneels, 2008). The second scale was monitoring of internal capabilities (MacInerney-May, 2012). The sudy proposed the first null hypothesis thus: $\mathrm{HO}_{\mathrm{i}}$ : There is no significant effect of sensing capabilities on firm performance.

Seizing Capabilities is the firm's learning, reflected by the ability to create internal knowledge, to acquire external knowledge, and to assimilate internal and external knowledge through knowledge sharing that are very important for capability creation (Cepeda \& Vera, 2007; Easterby-Smith et al., 2009; Vivas Lopez, 2005). Seizing capabilities was measured using three scales. These are knowledge acquisition, knowledge sharing and knowledge integration (MacInerney-May 2012; Pavlou \& El Sawy, 2011; Lichtenthaler, 2009; Jansen et al, 2008). The sudy proposed the second null hypothesis: $\mathrm{HO}_{i i \text { : }}$ There is no significant influence of seizing capabilities on firm performance.

Reconfiguration Capabilities refers to the creation and integration of internally or externally acquired capabilities. It is the transformation of existing capabilities, i.e. to change the form, shape, or appearance of capabilities existing within the firm (Teece, 2007) and redeployment or recombination of existing capabilities (Ahuja \& Katila, 2004). Reconfiguration capabilities variable was measured using two scales capabilities creation (MacInerney-May, 2012) and capabilities integration (MacInerney-May, 2012; Prieto et al. 2009; Pavlon \& El Sawy, 2011). The 
sudy proposed the third null hypothesis, $\mathrm{HO}_{i i i}$ : Reconfiguration capabilities have no significant effect on firm performance.

\section{Conceptual Framework}

In order to extend knowledge, the study undertook to examine how manufacturing firms embrace the concept of dynamic capabilities in their businesses. The Drnevich and Kriauciunas (2011) framework was adapted and modified as shown in figure 1 to depict the interplay of variables and to test the three hypotheses proposed in the previous section.

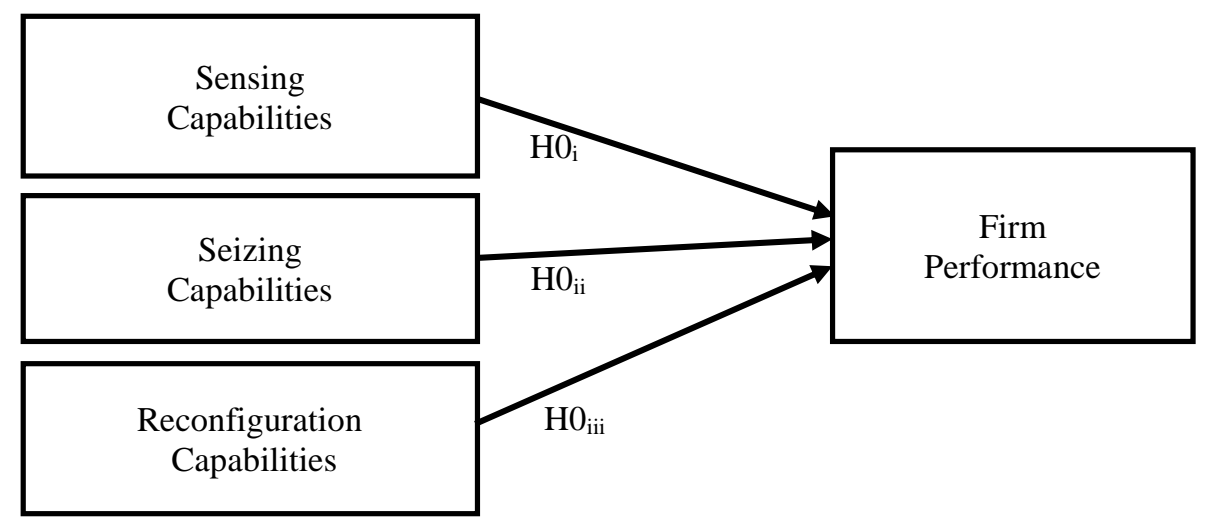

Figure 2: Conceptual Framework - Linking Firm Performance to Dynamic Capabilities

\section{Research Methodology}

A cross-sectional survey targeting manufacturing firms in Nairobi, Kenya, was undertaken using explanatory research design, duly anchored on logical positivism philosophical foundation (Saunders et al, 2007; Coltman, 2007; Babbie \& Benaquisto, 2009). The study's target population consisted of manufacturing firms operating in Nairobi County, Kenya. Respondents were Chief Executive Officers (CEOs) of these firms. The use of these senior managers as key informants was consistent with prior studies (Corsten \& Felde, 2005). There were 1496 manufacturing firms as provided by the Kenya Nation Bureau of Statitistics (KNBS). Based on anticipated population of 50\% (Naing et al., 2006), a confidence level of 95\%, a relative precision of $45 \%$ to $55 \%$ or a standard error of $5 \%$, and adjustment of $20 \%$ to cater for non-response, a sample size of 369 was determined for purposes of the study. A systematic random sampling approach i.e. the first listed firm, followed by every $4^{\text {th }}$ firm, was used to pick the 369 sampled firms (Frey et al., 2000; MacNealy, 1999). A questionnaire was used to collect primary data from the sampled firms (Hair, et al, 2006; Malhotra and Birks, 2007). The questionnaire was based on a seven (7) point Likert-type scale which 
enabled the collection of answers to specific closed research questions on aspects of performance of the firms in the market and the extent to which sensing, seizing and reconfiguration capabilities were deployed by these firms (Robson, 2002).

The Statistical Package for the Social Sciences (SPSS) software was used to analyze the data and to determine variable relationships (Hair et al, 2006). A response rate of $70.8 \%$ was achieved which was above the generally recommended threshold of between $50 \%$ and $60 \%$ (Babbie \& Benaquisto, 2009; Oso \& Onen, 2005). From the demographic profile of the respondents, the highest number of CEOs were aged between 30 and 50 years, forming $74.2 \%$ of the respondents. This meant that most of the CEOs of the manufacturing firms were relatively young, between 30 and 50 years old. It was also observed that $58.7 \%$ of the CEO's who responded were male and $41.3 \%$ were female.

After data collection and cleaning, psychometric tests were carried out to establish whether general assumptions of research were met, so as to avoid Type I or Type II errors (Osborne \& Waters, 2002). Reliability test was carried out to ensure the study achieved accurate representation of the total population under study (Joppe, 2000; Kirk \& Miller, 1986; Golafshani, 2003). The Table shows Cronbach's alpha reliability coefficients for the variables. The Cronbach alpha coefficients were: - Sensing capabilities (0.737), Seizing capabilities (0.685) and Reconfiguration capabilities (0.608). The Cronbach's alpha coefficient for firm performance (dependent) variable was 0.904 . Therefore apart from Reconfiguration capabilities, the other variables had coefficients about or above 0.700 . This was in harmony with Henson (2001) and Hair et al., (2006). The coefficient for reconfiguration capabilities variable was also above the recommended 0.60 cutoff (Sekaran, 2003; Hair et al, 2006; Garson, 2012).

Table 1: Cronbach's Alpha Reliability Test

\begin{tabular}{cccc}
\hline Construct & Dimensions & $\begin{array}{c}\text { Count of } \\
\text { Measures }\end{array}$ & $\begin{array}{c}\text { Cronbach's alpha } \\
\text { Coeff. }\end{array}$ \\
\hline Firm Performance & Firm Performance & 10 & 0.904 \\
Dynamic Capabilities & $\begin{array}{c}\text { Sensing Capabilities } \\
\text { Seizing Capabilities } \\
\text { Reconfiguration } \\
\text { Capabilities }\end{array}$ & 9 & 0.737 \\
& & 7 & 0.685 \\
&
\end{tabular}

Source: Study data, 2017.

Validity tests were carried out to ensure that the research truly measured that which it was intended to measure and presented truth in the research results (Golafshani, 2003; Lewis and Ritchie, 2003; DeRue et al., 2012; Arrindell et al., 2005). A principal component factor analysis was performed on all the items of the constructs in the study, using extraction 
with varimax rotation, in order to assess factor loadings for each variable and to achieve a simplified structure of the factors. The sampling adequacy measure of Kaiser-Meyer-Olkin (KMO) and sphericity measure of level of significance of Bartlet's coefficients for all the variables are summarized in the Table 2 . Factor loading for Firm Performance was successful for all its initial 10 items. The factor loading for Sensing Capabilities was for all its 8 items, Seizing Capabilities 8 out of 10 items and Reconfiguration Capabilities 6 out of 7 items. In all these cases, the Bartlet's Test of sphericity was significant, $\mathrm{p}<0.05$. The Eigene values and cumulative percentage variance contribution by the components were as shown on Table 2 below. These results therefore were considered acceptable (Hair et al., 2006; Tabachnick, 2007; Bartlett, et al, 2001) and provided the basis for proceeding to the next stage of analysis.

Table 2: Principal Component Factor Analysis Results

\begin{tabular}{ccccc}
\hline $\mathrm{N}=271$ & $\mathrm{FP}$ & $\mathrm{SC}$ & $\mathrm{SZ}$ & $\mathrm{RC}$ \\
\hline Kaiser-Meyer-Olkin & 0.927 & 0.834 & 0.754 & 0.723 \\
Bartlet's Test & $1256.728^{*}$ & $575.018^{*}$ & $329.398^{*}$ & $187.574^{*}$ \\
Eigene Value & 5.382 & 4.477 & 4.963 & 3.37 \\
Cummulative \% Variance & 53.82 & 55.961 & 49.627 & 48.144 \\
Factor Loading & 10 & 8 & 8 & 6 \\
\hline
\end{tabular}

Notes: ${ }^{*} p<0.05$; FP: Firm Performance; SC: Sensing Capabilities; SZ: Seizing Capabilities; RC: Reconfiguration Capabilities.

Source: Study data, 2017.

Descriptive analysis of the study variables showed firm performance had a mean score of 4.449 and standard deviation of 1.103. Its normal curve was skewed to the left (0.074) with a kurtosis of -0.230 . Sensing capabilities had a mean score of 3.843 and standard deviation of 0.991 with its normal curve skewed to the right $(-0.257)$ and had a kurtosis of -0.242 . Seizing capabilities had a mean score of 4.612 and standard deviation of 0.829 with its normal curve skewed to the left (0.020) and had a kurtosis of -0.149 . Reconfiguration capabilities had a mean score of 4.135 and standard deviation of 0.845 with its normal curve skewed to the left $(0.105)$ and had a kurtosis of -0.502 . These details are captured on Table 3.

Table 3: Descriptive Statistics

\begin{tabular}{ccrrr}
\hline Variable & Mean & Std. Dev & \multicolumn{1}{c}{ Skewness } & \multicolumn{1}{c}{ Kurtosis } \\
\hline Firm Performance & 4.449 & 1.103 & 0.074 & -0.23 \\
Sensing Capabilities & 3.843 & 0.991 & -0.257 & -0.242 \\
Seizing Capabilities & 4.612 & 0.829 & 0.02 & -0.149 \\
Reconfiguration Capabilities & 4.135 & 0.845 & 0.105 & -0.502 \\
\hline
\end{tabular}

Source: Study data, 2017. 
The study used Shapiro Wilk test to determine normality of the variables. The reason why Shapiro Wilk test was preferred is because the sample size for the study fell within the range of zero and 2,000 (Garson, 2012). According to Shapiro et al, (1968), a sample size falling within the range of 3 to 5000 is recommended. It was found, as indicated on Table 4, that apart from sensing capabilities, the rest of the variables' data showed $\mathrm{p}>0.05$, which meant that the null hypothesis on normality test hypothesis was not rejected and the data was therefore normally distributed (Pallant, 2007; Shapiro et al, 1968). Although results of sensing capabilities variable showed $\mathrm{p}<0.05$, the test statistic value was 0.987 , quite close to 1 and accordingly demonstrated normalilty of data (Ahmad \& Khan, 2015).

Table 4: Normality of Variables

\begin{tabular}{ccccccc}
\hline \multirow{2}{*}{ Constructs } & \multicolumn{3}{c}{ Kolmogorov-Smirnov } & \multicolumn{3}{c}{ Shapiro-Wilk } \\
& Statistic & df & Sig. & Statistic & df & Sig. \\
\hline Firm Performance & 0.037 & 271 & 0.200 & 0.990 & 271 & 0.057 \\
Sensing Capabilities & 0.074 & 271 & 0.001 & 0.987 & 271 & 0.015 \\
Seizing Capabilities & 0.059 & 271 & 0.024 & 0.994 & 271 & 0.313 \\
Reconfiguration Capabilities & 0.061 & 271 & 0.018 & 0.989 & 271 & 0.047 \\
\hline
\end{tabular}

Source: Study data, 2017.

Homoscedasticity Test was undertaken to confirm whether the variance of errors was the same across all levels of the independent variables (homoscedasticity) or not (heteroscedasticity). A scatter plot of the distribution of the standardized residuals (errors) was done using the standardized predicted values (Huizingh, 2007). The plot, on Figure 2, shows that residuals or errors were randomly clustered close to the trend line, meaning they were evenly distributed.

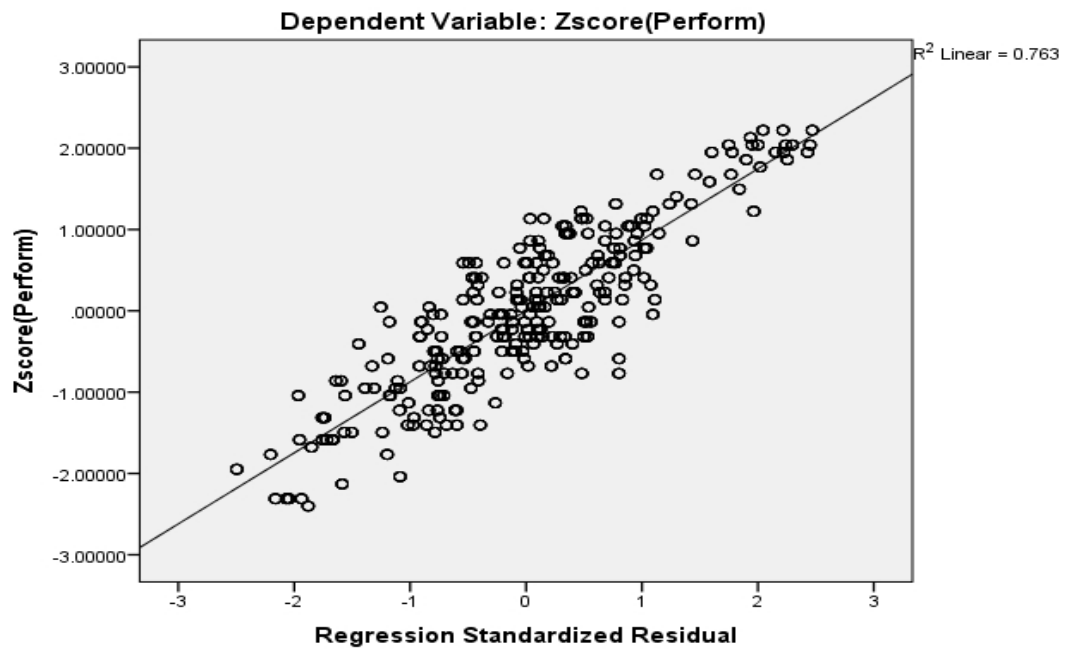

Figure 2: Homoscedasticity (Standardized Residuals) 
A multicolinearity diagnostics established variance inflation factors (VIF) of between 1.254 and 2.067, which were acceptably within the threshold of between 1 and 10 (Morrison, 2003). Tolerance values (TV) were between 0.484 and 0.797, well within the range of 0.2 to 1 (Agboola, 2006). The results indicate that there was no multicollinearity among the explanatory variables hence meeting the requisite assumption. These results are on Table 5.

Table 5: Collinearity Statistics

\begin{tabular}{ccc}
\hline Dependent variable: Firm Performance & Tolerance & VIF \\
\hline Sensing Capabilities & 0.546 & 1.832 \\
Seizing Capabilities & 0.721 & 1.388 \\
Reconfiguration Capabilities & 0.678 & 1.475 \\
\hline
\end{tabular}

Source: Study data, 2017.

A correlation test of variables revealed that there was positive correlation between firm performance and the three dimensions of dynamic capabilities - sensing capabilities $(0.394, \mathrm{P}<0.01)$, seizing capabilities $(0.360$, $\mathrm{P}<0.01)$ and reconfiguration capabilities $(0.413, \mathrm{P}<0.01)$. The correlation between sensing capabilities and seizing capabilities was $0.373, \mathrm{P}<001$. It was $0.492, \mathrm{P}<0.01$ between sensing capabilities and reconfiguration capabilities. These values fell within acceptable threshold for independent variables (Berry et al., 2006). These results are on Table 6.

Table 6: Correlations of Variables

\begin{tabular}{ccccc}
\hline & $1 \mathrm{FP}$ & $2 \mathrm{SC}$ & $3 \mathrm{ZC}$ & $4 \mathrm{RC}$ \\
\hline Firm Performance & 1 & & & \\
Sensing Capabilities & $0.394^{* *}$ & 1 & & \\
Seizing Capabilities & $0.360^{* *}$ & $0.373^{* *}$ & 1 & \\
Reconfiguration Capabilities & $0.413^{* *}$ & $0.492^{* *}$ & $0.372^{* *}$ & 1 \\
\hline
\end{tabular}

Pearson Correlation (2-tailed). Significance $* \mathrm{P}<0.05 ; * * \mathrm{P}<0.01$.

Source: Study data, 2017.

Regression analysis revealed that all the three variables - sensing capabilities $(B=0.215, P<0.01)$, seizing capabilities $(B=0.194, P<0.01)$ and reconfiguration capabilities $(B=0.182, P<0.001)$; had significant influence on firm performance. These variables combined, contributed $25.9 \%\left(\mathrm{R}^{2}=0.259\right)$ of the variance in firm performance. The regression results were used to test the following three hypotheses: - $\mathrm{HO}_{i}$ : There was no significant effect of sensing capabilities on firm performance, $\mathrm{HO}_{i i}$ : There was no significant influence of seizing capabilities on firm performance and $\mathrm{HO}_{i i i}$ : Reconfiguration capabilities had no significant effect on firm performance.

The coefficient for sensing capabilities $(B=0.215)$ was significant $(\mathrm{P}<0.01)$ and therefore the first null hypothesis $\left(\mathrm{HO}_{i}\right)$ was rejected and it was concluded that sensing capabilities had significant effect on firm 
performance. The coefficient for seizing capabilities was $\mathrm{B}=0.194, \mathrm{P}<0.01$ and the null hypothesis $\left(\mathrm{HO}_{i i}\right)$ was also rejected and a conclusion reached that seizing capabilities had significant effect on firm performance. Reconfiguration capabilities' coefficient of $\mathrm{B}=0.182, \mathrm{P}<0.001$ led to rejection of $\mathrm{HO}_{i i i}$ and conclusion that this variable had significant effect on firm performance. The detailed regression results are indicated in Table 7.

Table 7: Regression results on Firm Performance

\begin{tabular}{llllc}
\hline & $\begin{array}{c}\text { Unstd } B \\
\text { Coefficients }\end{array}$ & $\begin{array}{l}\text { Std. } \\
\text { Error }\end{array}$ & $\begin{array}{l}\text { Std Beta } \\
\text { Coefficients }\end{array}$ & $t$ \\
\hline (Constant) & $8.236 \mathrm{E}-16$ & 0.023 & & 0.000 \\
Zscore (SC) & $0.215^{* * *}$ & 0.029 & 0.215 & 7.518 \\
Zscore (ZC) & $0.194^{* * *}$ & 0.026 & 0.194 & 7.454 \\
Zscore (RC) & $0.182^{* * *}$ & 0.028 & 0.182 & 6.486 \\
$\mathrm{R}$ & 0.509 & & & \\
$\mathrm{R}^{2}$ & 0.259 & & & \\
Adj. $\mathrm{R}^{2}$ & 0.255 & & & \\
\hline
\end{tabular}

Notes: Significance $* \mathrm{P}<0.05 ; * * \mathrm{P}<0.01 ; * * * \mathrm{P}<0.001$. Dependent Variable: Zscore (FirmPerformance). Unstd: Unstandardized coefficients. Std: Standardized coefficients. SC:

Sensing Capabilities. ZC: Seizing Capabilities. RC: Reconfiguration Capabilities. Source: Study data, 2017.

\section{Conclusion}

Extant literature on dynamic capabilities consists largely of conceptual and theoretical discussions. Considering the predictors of firm performance have mostly remained conceptual, this research was an attempt to test the concept in an empirical setting. The study was premised on linking firm performance to sensing capabilities, seizing capabilities and reconfiguration capabilities. It was concluded that those firms that embrace a paradigm shift from conventional manufacturing to models that are based on appropriate dynamic capabilities improve their performance.

Hypotheses test results indicated that sensing capabilities was a predictor of firm performance. This result corroborated the findings by, among other studies, Osisioma et al, (2016), Li \& Liu (2014), Woldesenbet, et al (2012), Karagouni et al, 2012 and Wu (2010). In their initial conceptual model, Gathungu \& Mwangi (2012) highlighted that sensing capabilities were useful in the identification and assessment of opportunities. The study found that seizing capabilities predict firm performance, which is in harmony with Pandza and Holt (2007). The results further fitted into the contemplated findings of the theoretical conceptual framework proposed by Kocoglu et al (2015) on the differential relationship between absorptive capacity and product innovativeness. Seizing capabilities are about pro-activeness, a response to opportunities, and is an appropriate approach for firms that are facing competition (Lumpkin \& Dess, 2001). It was also observed that reconfiguration capabilities had a significant effect on firm performance, 
corroborating a previous study carried out on the Indian SMEs (Batra et al., 2015) that concluded that firms which reconfigured their resources according to the prevailing opportunities, were more likely to succeed. This further supported the results Cao (2011) that targeted international retailers in China on shaping, seizing and reconfiguration of opportunities and threats.

The study results provide insights into the degree of change of firm performance when sensing capabilities, seizing capabilities and reconfiguration capabilities are deployed. Practicing managers find some useful implications for application in designing strategies used in enhancing and sustaining firm performance. Notably, this avails an appropriate model for use when acquiring resources and selecting the competencies and capabilities that would avail desired results efficiently and effectively. The conceptualization of the model extends existing research using empirical approach and the results make a valuable contribution to strategic theories of Resource-Based View (Alvarez \& Busenitz, 2001) and Dynamic Capabilities. The study also informs management practice, industry and government policy formulation to come up with appropriate guidelines in addressing any firm vulnerability to the ever changing operating environment and therefore achieve sustainable industry or sectoral performance.

\section{References:}

1. Adenikinju, A., Söderling, L., Soludo, C., \& Varoudakis, A. (2002). Manufacturing Competitiveness in Africa: Evidence from Cameroon, Côte d'Ivoire, Nigeria, and Senegal. Economic Development and Cultural Change, Vol.50.

2. Agboola, A. K. (2006). Assessing the awareness and perceptions of academic staff in using e-learning tools for instructional delivery in a post-secondary institution: A case study. The Innovation Journal: The Public Sector Innovation Journal, 11(3), 1-12.

3. Ahmad, F., \& Khan, R. A. (2015). A power comparison of various normality tests. Pakistan Journal of Statistics and Operation Research, 11(3).

4. Ahuja, G., \& Katila, R. (2004). Where do resources come from? The role of idiosyncratic situations. Strategic Management Journal, 25(89), 887-907.

5. Alvarez, S. A., \& Busenitz, L. W. (2001). The entrepreneurship of resource-based theory. Journal of management, Vol.27.

6. Aramand, M., \& Valliere, D. (2012). Dynamic capabilities in entrepreneurial firms: A case study approach. Journal of International Entrepreneurship, 10(2), 142-157. 
7. Arend, R. J. (2014). Entrepreneurship and dynamic capabilities: How firm age and size affect the capability enhancement-SME performance relationship. Small Business Economics, Vol.42.

8. Arrindell, W. A., Akkerman, A., Bagés, N., Feldman, L., Caballo, V. E., Oei, T. P., \& Davis, M. (2005). The short-EMBU in Australia, Spain, and Venezuela. European Journal of Psychological Assessment, 21(1), 56-66.

9. Babbie, E. R., \& Benaquisto, L. (2009). Fundamentals of social research. Cengage Learning.

10. Barney, J. B. (2005). Expectations, Luck, and Business Strategy. Knowledge Management: Critical Perspectives on Business and Management, 2(10), 219.

11. Barney, J. and Clark D. N. (2007). Resource-based theory. New York: Oxford.

12. Bartlett, E. J; Kotrlik, W.J and Higins, C.C., (2001). Organizational Research: Determining Appropriate Sample Size in Survey Research

13. Batra, S., Sharma, S., Dixit, M. R., \& Vohra, N. (2015). Strategic orientations and innovation in resource-constrained SMEs of an emerging economy. The Journal of Entrepreneurship, 24(1)

14. Berry, K., Wearden, A., Barrowclough, C., \& Liversidge, T. (2006). Attachment styles, interpersonal relationships and psychotic phenomena in a non-clinical student sample. Personality and Individual Differences, 41(4), 707-718.

15. Bititci, U. S., Mendibil, K. T., \& Maguire, C. (2010). High value manufacturing: a case study in transformation. Proceedings of the Institution of Mechanical Engineers, Part B: Journal of Engineering Manufacture, Vol. 224.

16. Cao, L. (2011). Dynamic capabilities in a turbulent market environment: empirical evidence from international retailers in China. Journal of Strategic Marketing, 19(5), 455-469.

17. Carton, R. B., \& Hofer, C. W. (2006). Measuring organizational performance: Metrics for entrepreneurship and strategic management research. Edward Elgar Publishing.

18. Cepeda, G., \& Vera, D. (2007). Dynamic capabilities and operational capabilities: A knowledge management perspective. Journal of Business Research, 60(5), 426-437.

19. Chmielewski, D. A., \& Paladino, A. (2007). Driving a resource orientation: reviewing the role of resource and capability characteristics. Management Decision, 45(3), 462-483.

20. Coltman, T. (2007). Why build a customer relationship management capability? The Journal of Strategic Information Systems, Vol.16 
21. Combs, J. G., Crook, T. R. \& Shook, C. L. (2005). The dimension of organizational performance and its implications for strategic management research.

22. Corsten, D., \& Felde, J. (2005). Exploring the performance effects of key-supplier collaboration: an empirical investigation into Swiss buyer-supplier relationships. International Journal of Physical Distribution \& Logistics Management, 35(6), 445-461.

23. Cronin, J. J., Brady, M. K., \& Hult, G. T. M. (2000). Assessing the effects of quality, value, and customer satisfaction on consumer behavioral intentions in service environments. Journal of retailing, 76(2), 193-218.

24. Danneels, E. (2008). Organizational antecedents of second-order competences. Strategic Management Journal, Vol.29.

25. DeRue, D. S., Nahrgang, J. D., Hollenbeck, J. R., \& Workman, K. (2012). A quasi-experimental study of after-event reviews and leadership development. Journal of Applied Psychology, 97(5).

26. Drnevich, P. L., \& Kriauciunas, A. P. (2011). Clarifying the conditions and limits of the contributions of ordinary and dynamic capabilities to relative firm performance. Strategic Management Journal, Vol.32.

27. Easterby-Smith, M., Lyles, M. A., \& Peteraf, M. A. (2009). Dynamic capabilities: Current debates and future directions. British Journal of Management, 20(s1).

28. Eisenhardt, K. M., \& Martin, J. A. (2000). Dynamic capabilities: what are they? Strategic management journal, Vol.21.

29. Farjoun, M. (2002). Towards an organic perspective on strategy. Strategic Management Journal, 23(7), 561-594.

30. Filatotchev, I., Liu, X., Buck, T., \& Wright, M. (2009). The export orientation and export performance of high technology SMEs in emerging markets: The effects of knowledge transfer by returnee entrepreneurs. Journal of International Business Studies, Vol.40.

31. Frey, L., Botan, C. H., \& Kreps, G. (2000). Investigating communication. NY: Allyn \& Bacon.

32. Garson, G. D. (2012). Testing statistical assumptions. Asheboro, NC: Statistical Associates Publishing.

33. Gathungu, J. M., \& Mwangi, K. (2012). Dynamic Capabilities, Talent Development and Firm Performance. DBA Africa Management Review, 2(3), 83-100.

34. Glick, W. H., Washburn, N. T., \& Miller, C. C. (2005). The myth of firm performance. In Annual Meeting of the Academy of Management. 
35. Golafshani, N. (2003). Understanding reliability and validity in qualitative research. The qualitative report, 8(4), 597-606.

36. Hair, J. F., Black, W. C., Babin, B. J., Anderson, R. E., \& Tatham, R. L. (2006). Multivariate data analysis (Vol. 6). Upper Saddle River, NJ: Pearson Prentice Hall.

37. Halawi, L. A., McCarthy, R. V., \& Aronson, J. E. (2006). Knowledge management and the competitive strategy of the firm. The learning organization, 13(4), 384-397.

38. Hatton, T. J., \& Williamson, J. G. (2003). Demographic and economic pressure on emigration out of Africa. The Scandinavian Journal of Economics, 105(3), 465-486.

39. Helfat, C. E., Finkelstein, S., Mitchell, W., Peteraf, M., Singh, H., Teece, D., \& Winter, S. G. (2009). Dynamic capabilities:Understanding strategic change in organizations.John Wiley \& Sons.

40. Henson, R. K. (2001). Understanding internal consistency reliability estimates: A conceptual primer on coefficient alpha. Measurement and evaluation in counseling and development, 34(3).

41. Huizingh, E. (2007). Applied statistics with SPSS. Sage.

42. Jansen, J. J., George, G., Van den Bosch, F. A., \& Volberda, H. W. (2008). Senior team attributes and organizational ambidexterity: The moderating role of transformational leadership. Journal of Management Studies, 45(5), 982-1007.

43. Jantunen, A. (2005). Knowledge-processing capabilities and innovative performance: an empirical study. European Journal of Innovation Management, 8(3), 336-349.

44. Joppe, G. (2000). Testing reliability and validity of research instruments. Journal of American Academy of Business Cambridge, 4(1/2), 49-54.

45. Karagouni, G., Protogerou, A., \& Caloghirou, Y. (2012, September). Dynamic and autotelic capabilities in knowledge-intensive, low-tech ventures. In 7th European Conference on Innovation and Entrepreneurship, Escola Superior de Gestão e Tecnologia, Instituto Politécnico de Santarém, Portugal (pp. 20-21).

46. Kirk, J., \& Miller, M. L. (1986). Reliability and validity in qualitative research. Sage.

47. Kocoglu, I., Akgün, A. E., \& Keskin, H. (2015). The differential relationship between absorptive capacity and product innovativeness: a theoretically derived framework. International Business Research, $8(7), 108$. 
48. Lewis, J., \& Ritchie, J. (2003). Generalising from qualitative research. Qualitative research practice: A guide for social science students and researchers, 263-286.

49. Li, D. Y., \& Liu, J. (2014). Dynamic capabilities, environmental dynamism, and competitive advantage: Evidence from China. Journal of Business Research, 67(1), 2793-2799.

50. Lichtenthaler, U. (2009). Absorptive capacity, environmental turbulence, and the complementarity of organizational learning processes. Academy of Management Journal, Vol.52.

51. Lopez, S.V. (2005). Competitive advantage and strategy formulation: The key role of dynamic capabilities. Management decision, Vol.43.

52. Lumpkin, G. T., \& Dess, G. G. (2001). Linking two dimensions of entrepreneurial orientation to firm performance: The moderating role of environment and industry life cycle. Journal of business venturing, 16(5), 429-451.

53. MacInerney-May, K. (2012). The Value of Dynamic Capabilities for Strategic Management, Universität zu Köln.

54. MacNealy, M. S. (1999). Strategies for empirical research in writing. Longman

55. Malhotra, N. K., \& Birks, D. F. (2007). Marketing research: An applied approach. Pearson Education.

56. Morrison, C. M. (2003). Interpret with caution: Multicollinearity in multiple regression of cognitive data. Perceptual and motor skills, 97(1), 80-82.

57. Naing, L., Winn, T., \& Rusli, B. N. (2006). Practical issues in calculating the sample size for prevalence studies. Archives of orofacial Sciences, 1, 9-14.

58. Osborne, J. W., \& Waters, E. (2002). 1 Four Assumptions Of Multiple Regression That Researchers Should Always Test.

59. Osisioma, H. E., Nzewi, H. N., \& Mgbemena, I. C. (2016). Dynamic Capabilities and Performance of Selected Commercial Banks in Awka, Anambra State, Nigeria.

60. Oso, W. Y., \& Onen, D. (2005). A Guide to writing Research Proposals and Reports.

61. Pallant, J. (2007). SPSS survival manual: A step-by-step guide to data analysis using SPSS version 15. Nova Iorque: McGraw Hill.

62. Pandza, K., \& Holt, R. (2007). Absorptive and transformative capacities in nanotechnology innovation systems. Journal of Engineering and Technology Management, 24(4), 347-365.

63. Park, S. H., \& Luo, Y. (2001). Guanxi and organizational dynamics: Organizational networking in Chinese firms. Strategic management journal, Vol.22. 
64. Pavlou, P. A., \& El Sawy, O. A. (2011). Understanding the elusive black box of dynamic capabilities. Decision Sciences, 42(1), 239-273.

65. Polonsky, M. J., \& Scott, D. (2005). An empirical examination of the stakeholder strategy matrix. European Journal of Marketing, 39(9/10), 1199-1215.

66. Prieto, I. M., Revilla, E., \& Rodríguez-Prado, B. (2009). Building dynamic capabilities in product development: How do contextual antecedents matter?. Scandinavian Journal of Management, 25(3), 313-326.

67. Ramachandran, V. (2011). Strategic corporate social responsibility: A dynamic capabilities perspective. Corporate Social Responsibility and Environmental Management, Vol.18.

68. Richard, P. J., Devinney, T. M., Yip, G. S., \& Johnson, G. (2009). Measuring organizational performance: Towards methodological best practice. Journal of management Vol.35.

69. Robson, C. (2002). Real world research: A resource for social scientists and practitioner-researchers. Vol. 2. Oxford: Blackwell.

70. Santos, J. B., \& Brito, L. A. L. (2012). Toward a subjective measurement model for firm performance. BAR-Brazilian Administration Review, Vol.9.

71. Saunders, M., Lewis, P., \& Thornhill, A. (2007). Research methods for business students. Financial Times.

72. Sekaran, U. (2003). Research Methods for Business: A skill-bulding approach. New York: John Willey and Son. Inc Year.

73. Shapiro, S. S., Wilk, M. B., \& Chen, H. J. (1968). A comparative study of various tests for normality. Journal of the American Statistical Association, 63(324), 1343-1372.

74. Tabachnick, B. G., \& Fidell, L. S. (2007). Multivariate analysis of variance and covariance. Using multivariate statistics, 3, 402-407.

75. Tallon, P. P. (2008). Inside the adaptive enterprise: an information technology capabilities perspective on business process agility. Information Technology and Management, 9(1), 21-36.

76. Teece, D. J. (2007). Explicating dynamic capabilities: the nature and micro-foundations of (sustainable) enterprise performance. Strategic management journal, Vol.28.

77. Vivas Lopez, S. (2005). Competitive advantage and strategy formulation: The key role of dynamic capabilities. Management decision, 43(5), 661-669.

78. Whetten, D. A. (2006). Albert and Whetten revisited: Strengthening the concept of organizational identity. Journal of management inquiry, 15(3), 219-234. 
79. Wilden R., Gudergan, S. P., Nielsen, B. B., \& Lings, I. (2013). Dynamic capabilities and performance: strategy, structure and environment. Long Range Planning, Vol.46.

80. Winter, S. G. (2003). Understanding dynamic capabilities. Strategic management journal,, $\mathrm{Vol} .24$.

81. Woldesenbet, K., Ram, M., \& Jones, T. (2012). Supplying large firms: The role of entrepreneurial and dynamic capabilities in small businesses. International Small Business Journal, 30(5), 493-512.

82. Wu, L. Y. (2010). Applicability of the resource-based and dynamiccapability views under environmental volatility. Journal of Business Research, 63(1), 27-31.

83. Zahra, S. A., \& George, G. (2002). Absorptive capacity: A review, reconceptualization, and extension. Academy of management review, 27(2), 185-203.

84. Zott, C. (2003). Dynamic capabilities and the emergence of intraindustry differential firm performance: insights from a simulation study. Strategic management journal, Vol.24. 